\title{
Phenotypes, antibacterial-resistant profile, and virulence-associated genes of Salmonella serovars isolated from retail chicken meat in Egypt
}

\author{
Amal Awad ${ }^{1}$, Mayada Gwida², Eman Khalifa ${ }^{3}$ and Asmaa Sadat ${ }^{1}$
}

1. Department of Bacteriology, Mycology and Immunology, Faculty of Veterinary Medicine, Mansoura University, 35516, Egypt; 2. Department of Hygiene and Zoonoses, Faculty of Veterinary Medicine, Mansoura University, 35516, Egypt;

3. Department of Microbiology, Faculty of Veterinary Medicine, Matrouh University, Egypt.

Corresponding author: Amal Awad, e-mail: amalabdo@mans.edu.eg

Co-authors: MG: mayada_gwida@mans.edu.eg, EK:dr_eman_vet@yahoo.com, AS: asmaasadat@mans.edu.eg

Received: 04-09-2019, Accepted: 21-01-2020, Published online: 11-03-2020

doi: www.doi.org/10.14202/vetworld.2020.440-445 How to cite this article: Awad A, Gwida M, Khalifa E, Sadat A (2020) Phenotypes, antibacterial-resistant profile, and virulence-associated genes of Salmonella serovars isolated from retail chicken meat in Egypt, Veterinary World, 13(3): 440-445.

\section{ABSTRACT}

Aim: The present study was designed to investigate the occurrence and distribution of Salmonella serotypes in chicken meat samples, and to explore the susceptibility of the strains to antimicrobials, as well as their virulence-associated genes.

Materials and Methods: Two-hundred retail chicken meat samples from different shops, as well as 25 stool specimens from retail shop workers, were included in the study. The collected samples were examined bacteriologically for the presence of salmonellae. Salmonella isolates were serotyped using a slide agglutination test for $\mathrm{O}$ and $\mathrm{H}$ antigens and were screened for the presence of five virulence genes (stn, pef, invA, $s o p \mathrm{~B}$, and $a v r \mathrm{~A}$ ) using a uniplex polymerase chain reaction assay and for their susceptibility to 18 antimicrobial agents using the disk diffusion method.

Results: Thirty-one Salmonella isolates belonging to 12 different serovars were identified. Salmonella Enteritidis and Salmonella Kentucky were the dominant serovars (22.6\% each). Salmonella isolates displayed a high antibiotic resistance against erythromycin, sulfamethoxazole/trimethoprim, doxycycline, cephalexin, cefaclor, tetracycline, polymyxin B, cefuroxime, vancomycin, and streptomycin. All Salmonella isolates exhibited multidrug resistance (MDR) and demonstrated different virulence genes. The majority of Salmonella serovars $(87.1 \%)$ harbored sop B gene, 54.8\% carried avrA and pef genes, while all isolates carried invA and stn genes.

Conclusion: The presence of virulent MDR Salmonellae in raw chicken meat could allow the possibility of transmission of these resistant serovars to humans. Therefore, strict hygienic measures should be followed on the whole poultry production chain to decrease the potential transmission of Salmonella infection from poultry meat to humans.

Keywords: antibacterial susceptibility, broilers meat, multidrug resistance, Salmonella, virulence.

\section{Introduction}

Foodborne pathogens such as Salmonella (S) enterica species represent an important worldwide public health problem. Salmonella remains one of the major zoonotic bacterial foodborne pathogens, resulting in 93.8 million annual cases among patients having gastroenteritis, with an estimated 155,000 deaths each year [1]. Poultry is considered the main reservoir for a significant number of infections with $S$. enterica species, involving cross-contamination events at both the farm and retail levels [2]. A diverse incidence of salmonellosis has been reported recently [3]. The clinical manifestations of the disease among human patients ranged from self-limiting gastroenteritis to severe invasive meningitis, septicemia, and osteomyelitis [4]. The majority of cases are caused by the fecal contamination of foods of animal origin or the consumption of poultry or its products [5].

Copyright: Awad, et al. Open Access. This article is distributed under the terms of the Creative Commons Attribution 4.0 International License (http://creativecommons.org/licenses/by/4.0/), which permits unrestricted use, distribution, and reproduction in any medium, provided you give appropriate credit to the original author(s) and the source, provide a link to the Creative Commons license, and indicate if changes were made. The Creative Commons Public Domain Dedication waiver (http://creativecommons.org/ publicdomain/zero/1.0/) applies to the data made available in this article, unless otherwise stated.
Monitoring Salmonella infection on poultry farms is a challenging problem and relies mainly on the application of biosecurity measures in the farm setting and the use of antibacterial agents [6]. However, the excessive use of antibacterial medications in the poultry industry, either as growth promoters or to treat disease, could result in the emergence of antibacterial resistance among Salmonella isolates with potential health hazards [7]. Multidrug-resistant (MDR) bacteria from poultry origins have the potential to transfer to humans through the food chain, a danger that has triggered serious public concern [8].

The degree of the pathogenicity of Salmonella infections in the host cell has been attributed to the presence of virulence genes which have a significant role in the occurrence of systemic infections [9]. The presence of the invA gene in Salmonella pathogenicity islands is associated with epithelial invasion and the production of proteins of the type III secretion system (T3SS) [10], while the stn gene mediates enterotoxin production and is often associated with acute gastroenteritis [11]. The plasmid-encoded fimbriae (pef) mediates intestinal adhesion in certain Salmonella serotypes [12], while the multiple function effector proteins encoded by the avrA and $s o p \mathrm{~B}$ genes 
in the T3SS could facilitate endothelial uptake and invasion [13]. Therefore, recognizing the existence and characterization of Salmonella in retail chicken meat is important for emerging effective treatment approaches to control salmonellosis.

Currently, it is difficult to assess the impact of retail chicken meat MDR on public health due to the limited availability of data in the study area. MDR in retail chicken meat is not systematically monitored in most Egyptian governorates, and the existing data are scarce.

The present study was designed to investigate the occurrence and distribution of Salmonella serotypes in chicken meat samples, and to explore the susceptibility of the strains to antimicrobials, as well as their virulence-associated genes

\section{Materials and Methods}

\section{Ethical approval}

This study did not need ethical approval. However, the procedures performed in the current study were in accordance with the ethical standards of the institutional and/or national research committee and those of Mansoura University.

\section{Samples collection}

A total of 200 samples were collected from 100 chicken carcasses (two samples from each carcass) from local retail chicken meat shops at Mansoura city, Dakahlia Province, Egypt, during the period between September 2017 and December 2017. In addition, 25 stool specimens were collected from retail shops workers in sterile cups. For chicken meat, the samples were collected separately in sterile polyethylene bags to prevent cross-contamination and kept in clean sterile containers to be transferred within an hour through insulated coolers containing cold packs bag to the laboratory for Salmonella isolation and identification.

\section{Bacteriological examination}

The procedures of Salmonella isolation and identification were performed, according to standard methods (ISO6579:2002; International Organization for Standardization 2002). Briefly, $25 \mathrm{~g}$ from each chicken meat sample were cut into small pieces by sterile scissors. Then add to a stomach bag containing $225 \mathrm{~mL}$ sterile Buffered Peptone Water (BPW) (Oxoid, Hampshire, England). For the stool samples,
$1 \mathrm{~g}$ was added to $9 \mathrm{ml} \mathrm{BPW}$, then all the samples were incubated at $37^{\circ} \mathrm{C}$ for $18 \mathrm{~h} .0 .1 \mathrm{~mL}$ of the pre-enriched broth was transferred to $10 \mathrm{~mL}$ of RappaportVassiliadis broth (Oxoid, Hampshire, England) and incubated at $42^{\circ} \mathrm{C}$ for $24 \mathrm{~h}$. A loopful of the enriched broth was then streaked on xylose lysine desoxycholate agar and incubated for $24 \mathrm{~h}$ at $37^{\circ} \mathrm{C}$. Biochemical examination of the suspected Salmonella colonies was performed, according to the (ISO6579:2002; International Organization for Standardization 2002) guidelines [14].

\section{Serotyping}

Serotyping of the biochemically identified Salmonella isolates was accomplished according to the Kauffmann-White-Le Minor technique on the basis of surface antigen identification using polyclonal antisera (Difco Laboratories, Detroit, USA) to determine the $\mathrm{O}$ (somatic) and $\mathrm{H}$ (flagellar) antigenic epitopes at the Department of Food Hygiene and Control, Faculty of Veterinary Medicine, Benha University.

\section{Molecular identification of Salmonella virulence-as- sociated genes}

Genomic DNA was extracted from the identified Salmonella serovars, according to Ramadan et al. [15]. The polymerase chain reaction (PCR) assays were conducted in individual reactions using an applied Biosystems 96-well Thermal Cycler to detect five Salmonella associated virulence genes (stn, pef, invA, $s o p \mathrm{~B}$, and $a v r \mathrm{~A}$ ). The sets of primer sequences and corresponding amplicon sizes are illustrated in Table- 1 . All PCR reactions were performed in a total volume of $25 \mu \mathrm{L}$ consisting of $12.5 \mu \mathrm{L}$ of $2 \times \mathrm{PCR}$ master mixes (Promega, Madison, USA), $6 \mu \mathrm{L}$ DNA templates, and $1 \mu \mathrm{L}$ of each primer (Metabion, Germany) brought to $25 \mu \mathrm{L}$ using DNA/RNA free water. PCR reactions and thermal conditions used were performed, according to the referenced authors (Table-1) $[9,16,17]$. An aliquot of each amplified product was subjected to electrophoresis in a $1.5 \%$ agarose gel. The separated bands were visualized and photographed under an ultraviolet transilluminator.

\section{Antibacterial susceptibility testing}

Salmonella serovars were tested for their antibiotic susceptibility against 18 different antimicrobial

Table-1: Primers sequences used in PCR for detection of virulence genes in Salmonella serovars.

\begin{tabular}{|c|c|c|c|c|}
\hline Primer & Sequence & Virulence factor & Amplified product & References \\
\hline stn & $\begin{array}{l}\text { TTG TGT CGC TAT CAC TGG CAA CC } \\
\text { ATT CGT AAC CCG CTC TCG TCC }\end{array}$ & Enterotoxin/Chromosome & $617 \mathrm{bp}$ & [9] \\
\hline Pef & $\begin{array}{l}\text { TGT TTC CGG GCT TGT GCT } \\
\text { CAG GGC ATT TGC TGA TTC C }\end{array}$ & Plasmid encoded fimbriae/Plasmid & 700 bp & \\
\hline invA & $\begin{array}{l}\text { GTGAAATTATCGCCACGTTCGGGCAA } \\
\text { TCATCGCACCGTCAAAGGAACC }\end{array}$ & Salmonella species/SPI-1 & 284 bp & {$[16]$} \\
\hline sopB & $\begin{array}{l}\text { TCA GAA GRC GTC TAA CCA CTC } \\
\text { TAC CGT CCT CAT GCA CAC TC }\end{array}$ & Translocated effector protein/SPI-5 & 517 bp & [17] \\
\hline avrA & $\begin{array}{l}\text { CCT GTA TTG AGC GTC TGG } \\
\text { AGA GCT TCG TTG AAT GTC C }\end{array}$ & Effector protein/SPI-1 & 422 bp & \\
\hline
\end{tabular}

$\mathrm{PCR}=$ Polymerase chain reaction 
Table-2: Distribution of Salmonella serovars in retail chicken meat samples.

\begin{tabular}{|c|c|c|c|c|c|}
\hline \multirow[t]{2}{*}{ Identified serotypes } & \multirow[t]{2}{*}{ Number of serotypes (31) } & \multirow[t]{2}{*}{ Prevalence \% } & \multirow[t]{2}{*}{ Group } & \multicolumn{2}{|c|}{ Antigenic structure } \\
\hline & & & & $\mathbf{0}$ & $\mathbf{H}$ \\
\hline Salmonella Kentucky & 7 & 22.6 & $\mathrm{C} 3$ & 8,20 & $\mathrm{i}: Z 6$ \\
\hline Salmonella Enteritidis & 7 & 22.6 & $\mathrm{D} 1$ & $1,9,12$ & $\mathrm{~g}, \mathrm{~m}:-$ \\
\hline Salmonella Typhimurium & 6 & 19.4 & B & $1,4,5,12$ & $\mathrm{i}: 1,2$ \\
\hline Salmonella Labadi & 2 & 6.5 & $\mathrm{C} 3$ & 8,20 & $\mathrm{~d}: Z 6$ \\
\hline Salmonella Molade & 2 & 6.5 & $\mathrm{C} 2$ & 8,20 & Z10:Z6 \\
\hline Salmonella Larochelle & 1 & 3.2 & $\mathrm{C} 1$ & 6,7 & $\mathrm{e}, \mathrm{h}: 1,2$ \\
\hline Salmonella Takoradi & 1 & 3.2 & $\mathrm{C} 2$ & 8,20 & $\mathrm{i}: 1,5$ \\
\hline Salmonella Tamale & 1 & 3.2 & $\mathrm{C} 3$ & 8,20 & Z29:e,n,Z15 \\
\hline Salmonella Papuana & 1 & 3.2 & $\mathrm{C} 1$ & 6,7 & $r, e, n, z 15$ \\
\hline Salmonella Infantis & 1 & 3.2 & $\mathrm{C} 1$ & 6,7 & $r: 1,5$ \\
\hline Salmonella Inganda & 1 & 3.2 & $\mathrm{C} 1$ & 6,7 & $\mathrm{Z} 10: 1,5$ \\
\hline Salmonella Bargny & 1 & 3.2 & $\mathrm{C} 3$ & 8,20 & $\mathrm{i}: 1,5$ \\
\hline
\end{tabular}

agents belonging to different antimicrobial classes through the disk diffusion method following Clinical and Laboratory Standards Institute guidelines [18]. The following antibiotic disks (Oxoid, Basingstoke, Hampshire, UK) were used: Polymyxin B (PB; $300 \mu \mathrm{g}$ ), azithromycin (AZM; $15 \mu \mathrm{g})$, cephalexin $(\mathrm{CL} ; 30 \mu \mathrm{g})$, cefuroxime $(\mathrm{CXM} ; 30 \mu \mathrm{g})$, cefaclor $(\mathrm{CEC} ; 30 \mu \mathrm{g})$, erythromycin $(\mathrm{E} ; 15 \mu \mathrm{g})$, sulfamethoxazole/trimethoprim (SXT; 23.75/1.25 $\mu \mathrm{g}$ ), streptomycin ( $\mathrm{S} ; 10 \mu \mathrm{g})$, neomycin $(\mathrm{N} ; 30 \mu \mathrm{g})$, vancomycin (VA; $30 \mu \mathrm{g}$ ), norfloxacin (NOR; $10 \mu \mathrm{g}$ ), doxycycline (DO; $30 \mu \mathrm{g})$, penicillin $(\mathrm{P} ; 10 \mu \mathrm{g})$, gentamycin $(\mathrm{CN} ; 10 \mu \mathrm{g})$, tetracycline (TE; $30 \mu \mathrm{g})$, amoxicillin (AX; $25 \mu \mathrm{g}$ ), AX/clavulanic acid (AMC; $30 \mu \mathrm{g}$ ), and rifampin (RA; $5 \mu \mathrm{g})$. The isolates were defined as MDR if they exhibited resistance to three or more antimicrobial classes.

\section{Results}

Out of the total examined chicken samples $(\mathrm{n}=200), 31(15.5 \%)$ Salmonella isolates were recovered. None of the examined workers stool samples' yielded positive results. The identified serogroups among Salmonella isolates were B, C1, C2, C3, and D. Group C3 was the predominant group in the obtained isolates (Table-2). Twelve serotypes were identified including, Salmonella Enteritidis $(\mathrm{n}=7), \quad$ Salmonella Kentucky $(\mathrm{n}=7)$, Salmonella Typhimurium $(\mathrm{n}=6)$, Salmonella Molade $(\mathrm{n}=2)$, Salmonella Labadi $(\mathrm{n}=2)$, Salmonella Takoradi $(\mathrm{n}=1)$, Salmonella Papuana $(\mathrm{n}=1)$, Salmonella Tamale $(\mathrm{n}=1)$, Salmonella Larochelle $(\mathrm{n}=1)$, Salmonella Infantis $(\mathrm{n}=1)$, Salmonella Inganda $(\mathrm{n}=1)$, and Salmonella Bargny $(\mathrm{n}=1)$. The Salmonella isolates demonstrated a high resistance against E (96.78\%), followed by SXT (93.55\%), DO and CL (93.55\%), CXM (83.33\%), CEC (87.19\%), S (80.65\%), PB (83.33\%), TE (83.88\%), P (70.97\%), AX (67.8\%), AMC (83.88\%), VA (83.88\%), RA (70.97\%), and AZM (58.07\%) (Table-3). In contrast, all recovered Salmonella isolates displayed a high sensitivity to NOR (100\%), CN (96.77\%), and N $(83.87 \%)$. MDR (resistance to three or more antimicrobials) was observed in all tested isolates (Table-4).
Table-3: Percentages of antimicrobial resistance among Salmonella serovars.

\begin{tabular}{|c|c|c|c|}
\hline $\begin{array}{l}\text { Antibiotic used } \\
(\mu \mathrm{g} / \text { disc })\end{array}$ & $\begin{array}{l}\text { Disk } \\
\text { code }\end{array}$ & $\begin{array}{c}\text { Sensitivity } \\
(\%)\end{array}$ & $\begin{array}{l}\text { Resistant } \\
\quad(\%)\end{array}$ \\
\hline Erythromycin $(15 \mu \mathrm{g})$ & $E$ & 3.22 & 96.78 \\
\hline Azithromycin $(15 \mu \mathrm{g})$ & AZM & 41.93 & 58.07 \\
\hline Cephalexin $(30 \mu \mathrm{g})$ & $\mathrm{CL}$ & 6.45 & 93.55 \\
\hline Cefuroxime $(30 \mu \mathrm{g})$ & CXM & 16.12 & 83.33 \\
\hline Cefaclor $(30 \mu \mathrm{g})$ & CEC & 12.90 & 87.19 \\
\hline $\begin{array}{l}\text { sulfamethoxazole } \\
\text { trimethoprim, } \\
(23.75 / 1.25 \mu \mathrm{g})\end{array}$ & SXT & 6.45 & 93.55 \\
\hline Doxycycline $(30 \mu \mathrm{g})$ & DO & 6.45 & 93.55 \\
\hline Tetracycline $(30 \mu \mathrm{g})$ & TE & 16.12 & 83.88 \\
\hline Polymyxin B $(300 \mu \mathrm{g})$ & PB & 16.12 & 83.33 \\
\hline Streptomycin $(10 \mu \mathrm{g})$ & $\mathrm{S}$ & 19.35 & 80.65 \\
\hline Gentamycin $(10 \mu \mathrm{g})$ & $\mathrm{CN}$ & 96.77 & 3.23 \\
\hline Neomycin $(30 \mu \mathrm{g})$ & $\mathrm{N}$ & 83.87 & 16.13 \\
\hline Pencillin G $(10 \mu \mathrm{g})$ & $\mathrm{P}$ & 29.03 & 70.97 \\
\hline Amoxacillin $(25 \mu \mathrm{g})$ & $A X$ & 32.26 & 67.8 \\
\hline $\begin{array}{l}\text { Amoxacillin/clavulanic } \\
\text { acid }(30 \mu \mathrm{g})\end{array}$ & AMC & 16.12 & 83.88 \\
\hline Norfloxacin $(10 \mu \mathrm{g})$ & NOR & 100 & 0.00 \\
\hline Rifampin $(5 \mu \mathrm{g})$ & RA & 29.03 & 70.97 \\
\hline Vancomycin $(30 \mu \mathrm{g})$ & VA & 16.12 & 83.88 \\
\hline
\end{tabular}

$\mathrm{E}=$ Erythromycin, $\mathrm{AZM}=$ Azithromycin, $\mathrm{CL}=$ Cephalexin, $\mathrm{CXM}=$ Cefuroxime, $\mathrm{CEC}=$ Cefaclor, $\mathrm{SXT}=$ Sulfamethoxazole/ trimethoprim, $\mathrm{DO}=$ Doxycycline, $\mathrm{TE}=$ Tetracycline, $\mathrm{PB}=$ Polymyxin $\mathrm{B}, \mathrm{S}=$ Streptomycin, $\mathrm{CN}=$ Gentamycin, $\mathrm{N}=$ Neomycin, $\mathrm{P}=$ Penicillin, $\mathrm{AX}=$ Amoxicillin,

$\mathrm{AMC}=\mathrm{AX} /$ clavulanic acid, $\mathrm{NOR}=$ Norfloxacin, $\mathrm{RA}=$ Rifampin, $\mathrm{VA}=$ Vancomycin

All Salmonella isolates were screened by uniplex PCR for the identification of virulence-associated genes (invA, stn, sop B, avrA, and pef) and all were positive for at least two of the screened genes. Both invA and stn genes were detected in 100\% of the tested isolates, while $\operatorname{sop} \mathrm{B}$ was harbored by 27 isolates $(87.1 \%)$ and both avrA and pef were found in 17 isolates $(54.8 \%)$. Interestingly, $S$. Enteritidis and $S$. Kentucky harbored high percentages of the virulence genes (Table-4).

\section{Discussion}

$S$. enterica infections are considered an economically relevant disease in the poultry industry in Egypt and a serious public health potential worldwide. 
Currently, there are over 2500 recognized Salmonella serovars [19]. In the present study, $15.5 \%(31 / 200)$ of the examined chicken meat samples were Salmonella positive. Similar results were previously reported from Central Ethiopia [20].

The frequency of $S$. Typhimurium in poultry meat has been reported previously in Egypt from Assiut city markets [21] and from Mansoura city [22]. In the former study, the authors have isolated Salmonella from 44\% of the examined raw chicken meat; while in the latter study, the authors have isolated different Salmonella serotypes (including $S$. Typhimurium, $S$. Kentucky, $S$. Molade, and $S$. Bargny) from processed chicken in a percent of $25.6 \%(30 / 120)$. On the other side, Tarabees et al. [23] isolated $S$. Enteritidis from 2\% (2/100) and $S$. Typhimurium from 3\% (3/100) of chicken meats. In contrast, a higher prevalence of Salmonella contamination was recorded in South Thailand (67.5\%) [24] and China (54.0\%) [25]. According to a meta-analysis of European Published surveys, the incidence of Salmonella spp. in poultry meat commercialized in Europe is estimated to be $7.10 \%$ (95\% confidence interval: $4.60-10.8 \%$ ) [26]. The diversity in the prevalence rates of Salmonella from retail chicken meat could reflect the differences in the level of hygiene followed during chicken handling and processing, the sampling time of the year, the sampling design, as well as diagnostic methods followed. The predominant Salmonella serovars identified in the present study were $S$. Enteritidis (n=7), $S$. Kentucky (n=7), and $S$. Typhimurium $(\mathrm{n}=6)$. Similar findings were previously reported in Egypt [22,27]. In the latter study, $77.4 \%(24 / 31)$ of the Salmonella isolates belonged to serogroups $\mathrm{C}$ and $\mathrm{B}$, aligning with results previously reported by Abdel-Maksoud et al. [28]. In the current study, seven isolates were serotyped as $S$. Enteritidis. According to the European Food Safety Authority report, approximately $74 \%$ of human zoonotic salmonellosis is caused by $S$. Enteritidis and $S$. Typhimurium [29]. It is imperative to discover the most common serotypes in the examined raw chicken meat to determine the point (s) of contamination at different stages during slaughtering, scalding, defeathering, evisceration, processing and handling, particularly in low hygienic poultry retail outlets.

Table-4: Virulence genes and antibiotic resistance profiles of Salmonella serovars.

\begin{tabular}{|c|c|c|c|}
\hline Pattern & Serovars & Virulence genes & Antimicrobial resistance profile \\
\hline 1 & S. Kentucky & stn, pef, invA & $T E, C X M, V A, E, P B, C E C, S, S T X, P, C L$ \\
\hline 2 & S. Kentucky & sopB, stn, invA & RA, CXM, VA, E, PB, CEC, DO, S, AMC, STX, AX, P, CL \\
\hline 3 & S. Kentucky & sopB, stn, invA & CN, TE, CXM, E, AZM, CEC, DO, S, AMC, ATX, P, CL \\
\hline 4 & S. Kentucky & sopB, stn, invA & RA, CXM, VA, E, AZM, PB, CEC, DO, S, AMC, STX, AX, P, CL \\
\hline 5 & S. Kentucky & sopB, stn, avr, pef, invA & CN, RA, TE, CXM, VA, E, AZM, PB, CEC, DO, S, AMC, STX, AX, P, CL \\
\hline 6 & S. Kentucky & sopB, stn, avr, pef, invA & $\mathrm{N}, \mathrm{TE}, \mathrm{CXM}, \mathrm{PB}, \mathrm{DO}, \mathrm{STX}, \mathrm{CL}$ \\
\hline 7 & S. Kentucky & sopB, stn, pef, avr, invA & CN, N, RA, TE, CXM, VA, E, AZM, PB, CEC, DO, AMC, STX, AX, P, CL \\
\hline 8 & S. Enteritidis & sopB, stn, avr, pef, invA & RA, TE, CXM, VA, E, AZM, PB, CEC, DO, S, AMC, STX, AX, P, CL \\
\hline 9 & S. Enteritidis & sopB, stn, avr, invA & RA, TE, VA, E, PB, CEC, DO, S, AMC, AX, P, CL \\
\hline 10 & S. Enteritidis & sopB, stn, pef, invA & CN, RA, TE, CXM, VA, E, PB, CEC, DO, S, AMC, STX, AX, CL \\
\hline 11 & S. Enteritidis & sopB, stn, pef, invA & TE, CXM, VA, E, AZM, PB, CEC, DO, S, AMC, STX, AX, CL \\
\hline 12 & S. Enteritidis & sopB, stn, avr, invA & TE, CXM, E, AZM, PB, CEC, DO, S, AMC, STX, AX, CL \\
\hline 13 & S. Enteritidis & sopB, stn, avr, pef, invA & $\mathrm{N}, \mathrm{RA}, \mathrm{TE}, \mathrm{CXM}, \mathrm{VA}, \mathrm{E}, \mathrm{PB}, \mathrm{CEC}, \mathrm{DO}, \mathrm{S}, \mathrm{AMC}, \mathrm{STX}, \mathrm{AX}, \mathrm{P}, \mathrm{CL}$ \\
\hline 14 & S. Enteritidis & sopB, stn, avr, pef, invA & RA, TE, CXM, VA, E, AZM, PB, CEC, DO, S, AMC, STX, AX, P, CL \\
\hline 15 & S. Typhimurium & sopB, stn, pef, invA & TE, VA, E, DO, AMC, STX, P, CL \\
\hline 16 & S. Typhimurium & sopB, stn, pef, avr, invA & TE, CXM, VA, E, S, STX, P \\
\hline 17 & S. Typhimurium & sopB, stn, invA & RA, TE, CXM, E, AZM, PB, CEC, DO, S, AMC, STX, CL \\
\hline 18 & S. Typhimurium & sopB, stn, avr, invA & $\mathrm{RA}, \mathrm{TE}, \mathrm{VA}, \mathrm{E}, \mathrm{PB}, \mathrm{CEC}, \mathrm{DO}, \mathrm{S}, \mathrm{AMC}, \mathrm{AX}, \mathrm{P}, \mathrm{CL}$ \\
\hline 19 & S. Typhimurium & sopB, stn, avr, invA & RA, CXM, VA, E, AZM, PB, CEC, DO, S, AMC, STX, AX, P, CL \\
\hline 20 & S. Typhimurium & stn, pef, invA & CN, RA, TE, CXM, VA, E, AZM, PB, CEC, DO, S, AMC, STX, AX, P, CL \\
\hline 21 & S. Labadi & sopB, stn, invA & RA, TE, CXM, VA, E, AZM, PB, CEC, DO, S, AMC, STX, AX, P, CL \\
\hline 22 & S. Labadi & sopB, stn, avr, pef, invA & $\mathrm{CN}, \mathrm{N}, \mathrm{RA}, \mathrm{TE}, \mathrm{CXM}, \mathrm{VA}, \mathrm{E}, \mathrm{PB}, \mathrm{CEC}, \mathrm{DO}, \mathrm{S}, \mathrm{STX}, \mathrm{AX}, \mathrm{CL}$ \\
\hline 23 & S. Molade & sopB, stn, invA & RA, TE, CXM, VA, E, AZM, CEC, DO, S, AMC, STX, CL \\
\hline 24 & S. Molade & sopB, stn, avr, pef, invA & RA, TE, CXM, VA, E, AZM, PB, CEC, DO, S, AMC, STX, AX, P, CL \\
\hline 25 & S. Inganda & sopB, stn, avr, invA & RA, TE, CXM, VA, E, AZM, PB, CEC, DO, S, STX, CL \\
\hline 26 & S. Bargny & sopB, stn, avr, pef, invA & RA, TE, CXM, VA, E, PB, CEC, DO, AMC, STX, AX, CL \\
\hline 27 & S. Larochelle & stn, invA & RA, TE, CXM, VA, E, PB, DO, S, AMC, STX, P, CL \\
\hline 28 & S. Takoradi & sopB, stn, pef, invA & VA, E, PB, CEC, DO, S, AMC, STX, P, CL \\
\hline 29 & S. Tamale & sopB, stn, avr, invA & $E, P B, C E C, D O, A M C, A X, P$ \\
\hline 30 & S. Papuana & sopB, stn, avr, pef, invA & RA, TE, CXM, VA, E, AZM, CEC, DO, S, AMC, STX, AX, P \\
\hline 31 & S. Infantis & stn, invA & CN, N, RA, TE, CXM, VA, E, AZM, PB, CEC, DO, AMC, STX, AX, P, CL \\
\hline
\end{tabular}

S. Kentucky=Salmonella Kentucky, S. Enteritidis=Salmonella Enteritidis, $S$. Typhimurium=Salmonella Typhimurium, S. Labadi=Salmonella Labadi, S. Molade= Salmonella Molade, S. Inganda=Salmonella Inganda, S. Bargny=Salmonella Bargny, S. Larochelle=Salmonella Larochelle, S. Takoradi=Salmonella Takoradi, S. Tamale=Salmonella Tamale, S. Papuana =Salmonella Papuana, S. Infantis=Salmonella Infantis, TE=Tetracycline, $C X M=C e f u r o x i m e, V A=V a n c o m y c i n$, $\mathrm{E}=$ Erythromycin, $\mathrm{PB}=$ Polymyxin $\mathrm{B}, \mathrm{CEC}=$ Cefaclor, $\mathrm{S}=$ Streptomycin, $\mathrm{STX}=$ Trimethoprim/sulfamethoxazole, $\mathrm{P}=\mathrm{Penicillin}$, $\mathrm{CL}=$ Cephalexin, $\mathrm{RA}=$ Rifampin, $\mathrm{DO}=$ Doxycycline, $\mathrm{AMC}=\mathrm{AX} /$ clavulanic acid, $\mathrm{CN}=$ Gentamycin, $\mathrm{AZM}=\mathrm{Azithromycin}$, $\mathrm{N}=$ Neomycin 
The antibacterial susceptibility testing revealed that the identified Salmonella serovars were sensitive to NOR (100\%), CN (96.77\%), and N (83.87\%). Nearly, similar data were previously reported [30], while $83.88 \%$ of the obtained Salmonella serovars were resistant to AMC and $96.78 \%$ were resistant to E. Several studies have demonstrated that various patterns of antibacterial resistance exist in Salmonella isolates [27,30]. A high rate of MDR was found against most of the commonly used antibiotics. These findings should alert the farm owners to use alternative medications to combat the bacteria instead of using the traditional antibiotics against which bacterial resistance has become common. The current findings are similar to those previously reported in Spain and Turkey [31,32], and MDR Salmonella isolates from poultry origin have been reported worldwide [4,33,34]. The pattern of MDR observed in the present study highlights the drawbacks of the uncontrolled use of antimicrobials, which contributes to increasing the incidence of resistant pathogens among human infections. Hence, a continuous surveillance of antimicrobial resistance of zoonotic bacterial strains such as Salmonella spp. isolated from food and production environments will contribute to a successful control program.

The virulence of the obtained Salmonella strains is associated with a series of genes which is responsible for invasion, colonization, and spread within the infected host. The present study demonstrated various virulence genes among Salmonella serovars. For example, the invA and stn genes were harbored by $100 \%$ of Salmonella serovars, which are in agreement with Osman et al. [35] and Ahmed et al. [36]. It has been suggested that the invA gene is a specific marker for the molecular detection of Salmonella serotypes, while the stn gene is responsible for enterotoxin production [36]. In the current study, the prevalence of the $\operatorname{sop} \mathrm{B}$ gene was $87.1 \%$. This gene plays a significant role in the occurrence of diarrhea through activating secretory pathways or facilitating inflammation and altering ion balances within cells [36]. The avrA gene was detected in $54.8 \%$ of the obtained isolates. Other reports have indicated that this gene was only observed in serovars that cause severe salmonellosis in humans [37]. The pef gene was also identified in $54.8 \%$ of the isolates, highlighting the significance of fimbriae in the infection process. A similar detection rate (68\%) was previously reported by Hudson et al. [37]. In contrast, a low frequency $(6.7 \%)$ of the pef gene in Salmonella isolates was previously detected [36]. Interestingly, none of the examined stool samples yielded positive results, notwithstanding the fact that the risk of contracting the infection from contaminated products cannot be excluded.

\section{Conclusion}

Our findings provide evidence for the presence of MDR Salmonella serovars with a wide distribution of virulence genes in chicken meat. These findings raise the suspicion that retail chicken meat often harbors zoonotic Salmonella serovars, representing a potential public health hazard. The possibility of transmission of these MDR serovars to humans requires regular monitoring of the production chain and amended farming practices, with particularly strict regulation of antibiotic usage.

\section{Authors' Contributions}

AA designed the study, conducted the experiments, and revised the manuscript, MG wrote the manuscript and participated in carrying out experiments, and EK and AS shared in performing the experiments and reviewing the manuscript. All authors read and approved the final manuscript for publication.

\section{Acknowledgments}

The authors are thankful to Department of Bacteriology, Mycology and Immunology, Faculty of Veterinary Medicine, Mansoura University, Egypt for providing necessary facilities for the study. The authors are thankful to Stephen Marino (BfR, Berlin, Germany) for English editing. The authors did not receive any funds for this study.

\section{Competing Interests}

The authors declare that they have no competing interests.

\section{Publisher's Note}

Veterinary World remains neutral with regard to jurisdictional claims in published institutional affiliation.

\section{References}

1. World Health Organization. (2018) Salmonella (Nontyphoidal). Available from: https://www.who.int/newsroom/ fact-sheets/detail/salmonella-(non-typhoidal). Retrieved on 12-04-2019.

2. Antunes, P., Mourão, J., Campos, J. and Peixe, L. (2016) Salmonellosis: The role of poultry meat. Clin. Microbiol. Infect., 22(2): 110-121.

3. Vinueza-Burgos, C., Cevallos, M., Ron-Garrido, L., Bertrand, S. and De Zutter, L. (2016) Prevalence and diversity of Salmonella serotypes in Ecuadorian broilers at slaughter age. PLoS One, 11(7): e0159567.

4. Threlfall, E.J., Rowe, B. and Ward, L.R. (1993) A comparison of multiple drug resistance in Salmonellas from humans and food animals in England and Wales, 1981 and 1990. Epidemiol. Infect., 111(2): 189-198.

5. Hald, T., Aspinall, W., Devleesschauwer, B., Cooke, R., Corrigan, T., Havelaar, A.H. Gibb H.J., Torgerson, P.R., Kirk, M.D. Angulo, F.J., Lake, R.J., Speybroeck, N. and Hoffmann, S. (2016) World Health Organization estimates of the relative contributions of food to the burden of disease due to selected foodborne hazards: A structured expert elicitation. PLoS One, 11(1): e0145839.

6. Donado-Godoy, P., Gardner, I., Byrne, B.A., Leon, M., Perez-Gutierrez, E., Ovalle, M.V., Tafur, MA. and Miller, W. (2012) Prevalence, risk factors, and antimicrobial resistance profiles of Salmonella from commercial broiler farms in two important poultry-producing regions of Colombia. J. Food Prot., 75(5): 874-883.

7. Prestinaci, F., Pezzotti, P. and Pantosti, A. (2015) 
Antimicrobial resistance: A global multifaceted phenomenon. Pathog. Glob. Health, 109(7): 309-318.

8. Wu, H., Xia, X., Cui, Y., Hu, Y., Xi, M., Wang, X., Meng, J. and Yang, B. (2013) Prevalence of extended-spectrum $\beta$-lactamase-producing Salmonella on retail chicken in six provinces and two national cities in the people's republic of China. J. Food Prot., 76(12): 2040-2044.

9. Murugkar, H.V., Rahman, H. and Dutta, P.K. (2003) Distribution of virulence genes in Salmonella serovars isolated from man and animals. Indian J. Med. Res., 117: 66-70.

10. Suez, J., Porwollik, S., Dagan, A., Marzel, A., Schorr, Y.I., Desai, P.T., Agmon, V., McClelland, M., Rahav, G. and GalMor, O. (2013) virulence gene profiling and pathogenicity characterization of nontyphoidal Salmonella accounted for invasive disease in humans. PLoS One, 8(3): e58449.

11. Zou, M., Keelara, S. and Thakur, S. (2012) Molecular characterization of Salmonella enterica serotype enteritidis isolates from humans by antimicrobial resistance, virulence genes, and pulsed-field gel electrophoresis. Foodborne Pathog. Dis., 9(3): 232-238.

12. Bäumler, A.J., Gilde, A.J., Tsolis, R.M., Van Der Velden, A.W., Ahmer, B.M. and Heffron, F. (1997) Contribution of horizontal gene transfer and deletion events to development of distinctive patterns of fimbrial operons during evolution of Salmonella serotypes. J. Bacteriol., 179(2): 317-322.

13. Foley, S.L., Lynne, A.M. and Nayak, R. (2008) Salmonella challenges: Prevalence in swine and poultry and potential pathogenicity of such isolates. J. Anim. Sci., 86 Suppl 14: E149-E162.

14. International Organization for Standardization. (2002) Microbiology of food and animal feeding stuffs. In: Horizontal Methods for the Detection of Salmonella spp. International Organization for Standardization, Genève, Switzerland.

15. Ramadan, H., Awad, A. and Ateya, A. (2016) Detection of phenotypes, virulence genes and phylotypes of avian pathogenic and human diarrheagenic Escherichia coli in Egypt. J. Infect. Dev. Ctries., 10(06): 584-591.

16. Oliveira, S.D., Rodenbusch, C.R., Ce, M.C., Rocha, S.L.S. and Canal, C.W. (2003) Evaluation of selective and non-selective enrichment PCR procedures for Salmonella detection. Lett. Appl. Microbiol., 36(4): 217-221.

17. Huehn, S., La Ragione, R.M., Anjum, M., Saunders, M., Woodward, M.J., Bunge, C. Helmuth, R., Hauser, E., Guerra, B., Beutlich, J., Brisabois, A., Peters, T., Svensson, L., Madajczak, G., Litrup, E., Imre, A., HerreraLeon, S., Mevius, D., Newell, D.G. and Malorny, B. (2010) Virulotyping and antimicrobial resistance typing of Salmonella enterica serovars relevant to human health in Europe. Foodborne Pathog. Dis., 7(5): 523-535.

18. CLSI. (2017) Performance Standards for Antimicrobial Susceptibility Testing. $27^{\text {th }}$ ed. Clinical and Laboratory Standards Institute, CLSI supplements M100, Wayne, PA.

19. Poppe, C. (2000) Salmonella infections in the domestic fowl. In: Wray, C. and Wray. A., editors. Salmonella in Domestic Animals. CAB International, New York. p107-132,

20. Molla, B. and Mesfin, A. (2003) A survey of Salmonella contamination in chicken carcass and giblets in central Ethiopia. Rev. Méd. Vét., 154(4): 267-270.

21. El-Aziz, D.M. (2013) Detection of Salmonella Typhimurium in retail chicken meat and chicken giblets. Asian Pac. J. Trop. Biomed., 3(9): 678-681.

22. Elsayed, M., El-Gohary, F., Zakaria, A. and Gwida, M. (2019) Tracing of Salmonella contaminations throughout an integrated broiler production chain in Dakahlia Governorate, Egypt. Pak. Vet. J., 39(4): 558-562.

23. Tarabees, R., Elsayed, M.S., Shawish, R., Basiouni, S. and Shehat, A.A. (2017) Isolation and characterization of Salmonella Enteritidis and Salmonella Typhimurium from chicken meat in Egypt. J. Infect. Dev. Ctries., 11(4): 314-319.

24. Lertworapreecha, M., Sutthimusik, S. and Tontikapong, K. (2013) Antimicrobial resistance in Salmonella enterica isolated from pork, chicken, and vegetables in Southern Thailand. Jundishapur J. Microbiol., 6(1): 36-41.

25. Yang, B., Qu, D., Zhang, X., Shen, J., Cui, S., Shi, Y., Xi, M., Sheng, M., Zhi, S. and Meng, J. (2010) Prevalence and characterization of Salmonella serovars in retail meats of marketplace in Shaanxi, China. Int. J. Food Microbiol., 141(1-2): 63-72.

26. Gonçalves-Tenório, A., Silva, B.N., Rodrigues, V., Cadavez, V. and Gonzales-Barron, U. (2018) Prevalence of pathogens in poultry meat: A meta-analysis of European published surveys. Foods, 7(5): 69.

27. Halawa, M., Moawad, A., Eldesouky, I. and Ramadan, H. (2016) Detection of antimicrobial phenotypes, ß-lactamase encoding genes and class L INTEGRONS in Salmonella serovars isolated from broilers. Int. J. Poult. Sci., 15(1): 1-7.

28. Abdel-Maksoud, M., Abdel-Khalek, R., El-Gendy, A., Gamal, R.F., Abdelhady, H.M. and House, B.L. (2015) Genetic characterisation of multidrug-resistant Salmonella enterica serotypes isolated from poultry in Cairo, Egypt. Afr. J. Lab. Med., 4(1): 1-7.

29. European Food Safety Authority E. (2015) European Food Safety Authority and European Centre for Disease Prevention and Control. EFSA J., 13:4329.

30. Ammar, A.M., Mohamed, A.A., El-Hamid, M.I. and El-Azzouny, M.M. (2016) Virulence genotypes of clinical Salmonella serovars from broilers in Egypt. J. Infect. Dev. Ctries., 10(4): 337-346.

31. Lamas, A., Fernandez-No, I.C., Miranda, J.M., Vázquez, B., Cepeda, A. and Franco, C.M. (2016) Prevalence, molecular characterization and antimicrobial resistance of Salmonella serovars isolated from Northwestern Spanish broiler flocks (2011-2015). Poult. Sci., 95(9): 2097-105.

32. Yildirim, Y., Gonulalan, Z., Pamuk, S. and Ertas, N. (2011) Incidence and antibiotic resistance of Salmonella spp. on raw chicken carcasses. Food Res. Int., 44(3): 725-728.

33. Frye, J.G. and Fedorka-Cray, P.J. (2007) Prevalence, distribution and characterization of ceftiofur resistance in Salmonella enterica isolated from animals in the USA from 1999 to 2003. Int. J. Antimicrob. Agents., 30(2): 134-142.

34. Ahmed, A.M., Ishida, Y. and Shimamoto, T. (2009) Molecular characterization of antimicrobial resistance in Salmonella isolated from animals in Japan. J. Appl. Microbiol., 106(2): 402-409.

35. Osman, K.M., Marouf, S.H., Zolnikov, T.R. and AlAtfeehy, N. (2014) Isolation and characterization of Salmonella enterica in day-old ducklings in Egypt. Pathog. Glob. Health, 108(1): 37-48.

36. Ahmed,H.A., El-Hofy, F.I., Shafik, S.M.,Abdelrahman,M.A. and Elsaid, G.A. (2016) Characterization of virulence-associated genes, antimicrobial resistance genes, and class 1 integrons in salmonella enterica serovar typhimurium isolates from chicken meat and humans in Egypt. Foodborne Pathog. Dis., 13(6): 281-288.

37. Hudson, C.R., Quist, C., Lee, M.D., Keyes, K., Dodson, S.V., Morales, C., Sanchez, S., White, D.G. and Maurer, J.J. (2000) Genetic relatedness of Salmonella isolates from nondomestic birds in Southeastern United States. J. Clin. Microbiol., 38(5): 1860-1865. 